\title{
Strategic operational analysis based on balanced scorecard in present-day global economic environment
}

\author{
Sergey Krylov ${ }^{1, *}$ \\ ${ }^{1}$ Ural Federal University, Academic Department of Accounting, Analysis and Audit, Mira 19, 620002 \\ Ekaterinburg, Russian Federation
}

\begin{abstract}
The balanced scorecard (BSC) is one of well-trialled management instruments that are familiar to all market participants in the world. This fact allows for efficient utilization of BSC in conditions of globalization. The paper considers theoretical aspects of the applied strategic operational analysis (ASOA) based on the operational element of BSC to be applied in the research process of the strategic organization operational activity aspects and its production management. The methodology of the research is the BSC concept as well as the concept of the applied strategic analysis concept having been developed by the author. ASOA is depicted to encompass comparative assessment, variances diagnostics and indicators forecast of the operational BSC element within the strategic operational goals Due goods delivery, manufacturing cost and products quality compliance with customer's demand are to be analyzed. The results can be applied for managerial decisions development in the field of an operational organization activity. The author draws a conclusion is drawn that ASOA is a new and sufficiently effective tool to research strategic aspects of the organization operational activity and to form an analytical support for the strategic operational management in the presentday global economic environment, especially to ensure economic sustainability in emerging markets.
\end{abstract}

\section{Introduction}

In present-day economic environment every organization (enterprise, firm, and company) acquires a unique set of business processes ensuring value creation for its customers, developing and retaining its customer base within the target market segment as well as satisfying the requirements of its share holders in terms of high financial profitability. Meanwhile, there is a certain value chain model comprising three successive internal business processes: innovative process, operational process and after-sales service.

The author of the paper considers an operational process to be the basic one as it forms the basis of the continuing (core) operations and the organization performance and comprises production of goods and services and their delivery to its customers.

\footnotetext{
*Corresponding author: zali6770@yandex.ru
} 
Ensuring high operational process efficiency by decreasing the cost of production, goods and services delivery raising thereby their competitiveness rate is recognized as an essential goal of the continuing (core) operations and overall performance of any organization in the long term.

The goal is certain to be reached within the outcome strategic organization operational process management. In addition, an extent of the strategic decision implementation in the field of the operations management is to be assessed as well as the causes of variances (if any) are to be found, and a further situation development is to be forecast; a development and improvement of the appropriate analytical instrumentation being drivers of future success, especially to ensure economic sustainability in emerging markets.

In view of the mentioned above, the author of the paper seeks to consider his applied strategic analysis (ASA) based on the balanced scorecard (BSC) to be employed in the process of the analytical support development for the strategic operational activity management.

\section{Methods}

To enhance strategic management efficiency in difficult conditions of the present-day market economy we have developed the applied strategic analysis to improve its information-analytical support, to evolve theory, methodology and methods of the overall strategic economic activity aspects to the level of the financial analysis being an efficient research instrument of the financial aspects of the organization economic activity based on the financial indicators and described experience.

ASA, as a strategic management function, assumes an overall research of the strategic economic organization activity aspects based on the BSC $[1,2]$.

The balanced scorecard concept as an analytical instrument applied in the field of strategic management was developed by American scientists Robert Kaplan and David Norton [3] at the beginning of the 90s of the XX century, evolving both in their works [4-7] and those of other scientists studying economics [8-16], and was multiply tested. At present $\mathrm{BSC}$ is considered to be one of the essential instruments of the organization management system.

Balanced scorecard as a whole is understood as an aggregate of parameters featuring an overall organization performance in up-to-date market economy. It reflects a balance to be brought about between short-term and long-term goals, financial and non-financial indicators, basic and auxiliary parameters, as well as internal and external factors of the organization economic activity [3].

The scores of the balanced system are formed depending on the outlook and strategic goals of any particular organization and have individual features. They represent a balance between external accounting data for the owners (shareholders) and internal characteristics of the most significant business processes, innovations, training and growth that is the balance between the results of the organization performance and future growth. The system comprises a combination of objective quantity estimated data and subjective somewhat arbitrary parameters of future growth [5].

The main goal of the balanced scorecard is to transform a company strategy into specific tangible objectives, indicators and end up with events [12].

The balanced scorecard is founded on the cause and effect; results attain factors and their interrelation with financial data [10].

The balanced scorecard encompasses four basic interrelated elements: finance, a customer, internal business processes ones as well as training and personnel development element. The BSC scores enable to characterize comprehensively an activity of 
commercial, government and non-for-profit organizations, the scores being relatively few (about 25 scores in average, as a rule) [6].

It should be taken into consideration that basing on the balanced scorecard system special for any particular organization the applied strategic analysis lacks any standard methods. Hence, the ASA methods are special as well for any particular organization [1].

The goal of the applied strategic analysis implementation is to form analytical support for taking strategic management decisions.

The ASA accomplishment principle, a deduction principle presumes, firstly, an investigation of the general BSC indicators, then specific indicators. The principle defines general sequence of the ASA analysis according to the following leads: analysis of financial indicators, analysis of customer indicators, analysis of internal business-processes (process of after-sales service, operational process and innovative process) indicators, analysis of training and personnel development indicators [2].

The ASA commences from the comparative evaluation of the financial indicators and is completed by the forecast of training and personnel development.

When describing the ASA contents as a complex category of economics in his previous works the author assumed the applied strategic innovative analysis (ASIA) to be a kind of ASA presuming overall complex research of the strategic aspects of the organization innovative activity based on the innovative BSC's score [17], the applied strategic financial analysis (ASFA) implying overall complex research of the organization financial position by the BSC's financial score [18] as well as applied strategic customer analysis (ASCA) enabling to research overall strategic aspects of the organization sales performance by its BSC's customer score [19]. In the present paper the author considers the following kind of ASA - an applied strategic operational analysis.

\section{Results and Discussions}

An applied strategic operational analysis (ASOA), a kind of the applied strategic analysis, assumes a complex, comprehensive research of the strategic organization operational activity aspects basing on the operational element of its balanced scorecard. It can also be taken as a facilitating function of the strategic operations management.

The ASOA subject is the operational BSC element indicators (operational indicators) and the factors specifying them.

The ASOA object is strategic organization operational activity aspects.

The aim of the applied strategic operational analysis is to form an analytical support of making strategic decisions in the field of operations performance management.

The ASOA objectives are as follows: comparative assessment of the operational BSC element indicators, diagnostics of the operational BSC element indicators variances, forecast of the operational BSC element indicators.

Notice, that all the objectives of the applied strategic operational analysis are closely interrelated since each subsequent objective follows from the previous one. So the diagnostics is effected by the results of the comparative evaluation of the operational BSC element indicators and their forecast considers the diagnostics results.

Comparative assessment of the balanced scorecard operational element implies a comparison of their real and target figures, finding corresponding variances and their qualitative characteristics. The qualitative characteristics of the BSC operational element real and target figures variance depend largely on their value (Table 1).

The diagnostics of the balanced scorecard operational element indicators variance is based on the cause and effect links combining BSC values, the operational element included, into the balanced complex of general indicators and their specifying factors (results attaining factors). While diagnosing the BSC operational element indicators 
variance found are the results attaining factors, which are mostly impacting on the general or outcome indicators of the balanced scorecard operational element, and determined is its value. It should be noted that the outcome operational indicators of more specific BSC elements (innovative element, personnel training and development) could be considered as factors determining factoring indicators variances of more general operational element.

Table 1. Exemplary qualitative estimation of the variance characteristics of the BSC operational element's real and target figures.

\begin{tabular}{|c|c|}
\hline $\begin{array}{c}\text { Real figure variances values of the BSC } \\
\text { operational element from the target } \\
\text { ones, } \%\end{array}$ & $\begin{array}{c}\text { Qualitative estimation of the } \\
\text { BSC operational element real } \\
\text { figure from their target ones }\end{array}$ \\
\hline Up to $\pm 1 \%$ & Fairly small \\
\hline From $\pm 1 \%$ to $\pm 5 \%$ & Essential \\
\hline From $\pm 5 \%$ to $\pm 10 \%$ & Significant \\
\hline From $\pm 10 \%$ to $\pm 20 \%$ & Large \\
\hline $\pm 20 \%$ and higher & Very large \\
\hline
\end{tabular}

The operational BSC element indicators forecast are of the purposeful nature. In case of the objective conditions the values of the operational BSC element indicators forecast is targeted at the primordial determination and/or correction of the target values of the operational BSC element indicators and either determination of the specific ways of their attainment or the development of the events aimed at the elimination of the variance emerged between outcome and target values of the operational BSC element indicators in the future. Notice, that the forecast commences with the general (outcome) indicators, the factoring ones being derived from them.

The ASOA aspects imply proper strategic aspects, tactical aspects and operational aspects. Within the scope of the strategic aspect of the applied strategic operational analysis estimated, diagnosed and forecast are final BSC operational element indicators for the timeperiod of the developed strategy functioning, i.e., their strategic values. Within the frame of the tactical aspect of the applied strategic operational analysis estimated, diagnosed and forecast are interim BSC operational element indicators by the each year end, i.e., their tactical values. Within the scope of the operational aspect applied strategic operational analysis estimated, diagnosed and forecast are interim BSC operational element indicators by the end of each month, i.e., their operational values It should be noted, that all the ASOA aspects mentioned are interrelated and agreed: the results of the BSC operational element indicators values analysis make an impact on their tactical values and the results of the tactical values analysis - on the strategic ones.

The ASOA methodology instruments comprise an aggregate of techniques (ways, methods) to facilitate handling the essential problems of the analysis accomplished and, respectively, its goal reached. The basic methods of the applied strategic operational analysis include techniques of absolute, relative and average values, comparison, grouping, graphic and table methods, correlation-regression analysis, factoring analysis, cluster analysis, and expert evaluation methods.

The ASOA information base is the operational BSC element (Table 2), the formation comprising a number of steps: definition of the strategic goals of the operational process, construction of the strategic operational process map, selection of the operational process 
indicators, definition of the target operational process indicators values, development of the strategic operational events.

Table 2. BSC operational element of the organization development.

\begin{tabular}{|c|c|c|c|c|}
\hline $\begin{array}{c}\text { Key issue of the BSC } \\
\text { operational element }\end{array}$ & $\begin{array}{c}\text { Strategic goals of } \\
\text { the operational } \\
\text { process }\end{array}$ & $\begin{array}{c}\text { Operational } \\
\text { process } \\
\text { indicator }\end{array}$ & $\begin{array}{c}\text { Target } \\
\text { value }\end{array}$ & $\begin{array}{c}\text { Strategic } \\
\text { operational } \\
\text { event }\end{array}$ \\
\hline $\begin{array}{c}\text { What goals concerning } \\
\text { operational process are to } \\
\text { be set to attain the } \\
\text { following after-sales } \\
\text { service, customer and } \\
\text { financial goals, } \\
\text { respectively? }\end{array}$ & & & & \\
\cline { 2 - 5 } & & & & \\
\hline
\end{tabular}

The applied strategic operational analysis as a kind of the applied strategic analysis is carried out in compliance with the principle of deduction encompassing research firstly, general indicators of the BSC operational element then specific ones.

The basic components of the ASCA are the following:

1. Analysis of products due delivery.

2. Analysis of products manufacturing cost.

3. Analysis of products quality compliance with customer demands.

The process of the ASOA analysis exercise can be presented by means of considering its main objectives, i.e. comparative assesment, diagnostics of the variance and the forecast of the operational BSC element (Table 3).

Table 3. Matrix of the ASOA elements.

\begin{tabular}{|c|c|c|c|}
\hline \multirow{2}{*}{$\begin{array}{c}\text { Basic ASOA } \\
\text { elements (i) }\end{array}$} & \multicolumn{3}{|c|}{ Major ASOA objectives (j) } \\
\cline { 2 - 4 } & $\begin{array}{c}\text { Comparative } \\
\text { assessment of the } \\
\text { BSC operational } \\
\text { element indicator } \\
\text { values (1) }\end{array}$ & $\begin{array}{c}\text { Diagnostics of the } \\
\text { BSC operational } \\
\text { element indicator } \\
\text { values variances (2) }\end{array}$ & $\begin{array}{c}\text { Forecast of the BSC } \\
\text { operational element } \\
\text { indicator values (3) }\end{array}$ \\
\hline $\begin{array}{c}\text { Analysis of products } \\
\text { due delivery (1) }\end{array}$ & $\begin{array}{c}\text { Comparative } \\
\text { assessment of the } \\
\text { values of the products } \\
\text { due delivery indicator }\end{array}$ & $\begin{array}{c}\text { Diagnostics of the } \\
\text { products due delivery } \\
\text { indicator values } \\
\text { variances }\end{array}$ & $\begin{array}{c}\text { Forecast of the } \\
\text { products due } \\
\text { delivery indicator } \\
\text { values }\end{array}$ \\
\hline $\begin{array}{c}\text { Analysis of products } \\
\text { manufacturing cost } \\
\text { (2) }\end{array}$ & $\begin{array}{c}\text { Comparative } \\
\text { assessment of the } \\
\text { values of the products } \\
\text { manufacturing cost } \\
\text { indicator }\end{array}$ & $\begin{array}{c}\text { Diagnostics of the } \\
\text { products } \\
\text { manufacturing cost } \\
\text { indicator values } \\
\text { variances }\end{array}$ & $\begin{array}{c}\text { Forecast of the } \\
\text { products } \\
\text { manufacturing cost } \\
\text { indicator values }\end{array}$ \\
\hline $\begin{array}{c}\text { Analysis of products } \\
\text { quality compliance } \\
\text { with customer } \\
\text { demands (3) }\end{array}$ & $\begin{array}{c}\text { Comparative } \\
\text { assessment of the } \\
\text { values of the products } \\
\text { quality compliance } \\
\text { with customer } \\
\text { demands indicator }\end{array}$ & $\begin{array}{c}\text { Diagnostics of the } \\
\text { products quality } \\
\text { compliance with } \\
\text { customer demands } \\
\text { indicator values } \\
\text { variances }\end{array}$ & $\begin{array}{c}\text { Forecast of the } \\
\text { products quality } \\
\text { compliance with } \\
\text { customer demands } \\
\text { indicator values }\end{array}$ \\
\hline
\end{tabular}

Examples of the outcome and factoring indicators analyzed per every complex ASOA element are provided in Table 4. 
Table 4. Examples of the analyzed outcome and factoring indicators per every complex ASOA element.

\begin{tabular}{|c|c|c|}
\hline \multirow{2}{*}{ Basic ASOA elements } & \multicolumn{2}{|c|}{ Indicators analyzed } \\
\hline & Outcome & Factoring \\
\hline $\begin{array}{l}\text { 1. Analysis of products } \\
\text { due delivery }\end{array}$ & $\begin{array}{c}\text { Production cycle efficiency; } \\
\text { Goods and services delivery error } \\
\text { on the high side/on the lower } \\
\text { side; } \\
\text { A share of undue deliveries } \\
\text { within total goods and services } \\
\text { deliveries to customers. }\end{array}$ & $\begin{array}{l}\text { Production cycle length. Goods } \\
\text { and services delivery deadlines; } \\
\text { A number of undue goods and } \\
\text { services deliveries to customers. }\end{array}$ \\
\hline $\begin{array}{l}\text { 2. Analysis of products } \\
\text { manufacturing cost }\end{array}$ & $\begin{array}{c}\text { Variance of the standard (target) } \\
\text { total products manufacturing cost } \\
\text { values; } \\
\text { Variance of the standard (target) } \\
\text { different items manufacturing } \\
\text { cost values. }\end{array}$ & $\begin{array}{c}\text { The standard (target) total } \\
\text { products manufacturing cost } \\
\text { values; } \\
\text { The actual value of the total } \\
\text { products manufacturing cost; } \\
\text { The standard (target) value of the } \\
\text { different items manufacturing } \\
\text { cost; } \\
\text { The actual values of the different } \\
\text { items manufacturing cost. }\end{array}$ \\
\hline $\begin{array}{l}\text { 3. Analysis of } \\
\text { products quality } \\
\text { compliance with } \\
\text { customer demands }\end{array}$ & $\begin{array}{l}\text { A number of defects per a } \\
\text { million of finished goods; } \\
\text { A number of faulty goods per a } \\
\text { million of finished goods. }\end{array}$ & $\begin{array}{l}\text { A number of defects per a million } \\
\text { of finished goods found during } \\
\text { manufacturing process; } \\
\text { A number of goods returned, } \\
\text { claimed warranties and } \\
\text { guaranteed repairs; } \\
\text { Wastes and losses caused by } \\
\text { faulty goods. }\end{array}$ \\
\hline
\end{tabular}

The conceptual base of the applied strategic operational analysis, as a new instrument to research comprehensively strategic aspects of the organization operational activity through the balanced scorecard operational element, discussed above, defines some general contours of new research and performance leads, providing a theoretical basis for further ASOA development in terms of its practical application aspect.

The implications of future applied strategic operational analysis are as follows:

Detailed and specific ASOA methodology development in terms of the indicators of separate stages and strategic operational activity goals.

Development of the ASOA techniques for individual companies in different industries.

ASOA extension onto the continuing operational activity indicators being a derivative of the BSC operational element indicator.

Development of economic-mathematical models and computer programs enabling to apply ASOA for the operational activity management.

\section{Conclusions}

Completing a consideration of the applied strategic operational analysis a number of conclusions are drawn:

Applied strategic operational analysis as a kind of the applied strategic analysis is a new and sufficiently effective instrument to research strategic aspects of the organization operational activity forming analytical support for the strategic operational management;

Its methodology constitutes concepts of the balanced scorecard and applied strategic analysis; 
ASOA presumes comparative assessment, variances diagnostics and forecast of the BSC operationalr element indicators of the organization within its strategic goals of the operational process;

ASOA comprises analysis of products due delivery; analysis of products manufacturing cost; analysis of products quality compliance with customer demands;

ASOA commences from comparative assessment of outcome indicators, characterizing products due delivery and is completed by factoring indicators forecast of products quality compliance with customer demands;

Results of applied strategic operational analysis may be applied for the development and implementation decisions of long-term, medium-term and short-term character in the field of an organization operational activity, especially to ensure the economic sustainability of companies in emerging markets.

\section{References}

1. S. Krylov, Applied strategic analysis as further balanced scorecard concept development. Proceedings of the $11^{\text {th }}$ Eurasia Business and Economics Society (EBES) conference (Ekaterinburg, Russia, 35-42, 2013).

2. S. I. Krylov, Theoretical aspects of economic balanced scorecard analysis. Asian Journal of Finance \& Accounting, 6 (1), 90-109 (2014).

3. R. S. Kaplan, D. P. Norton, The balanced scorecard: Measures that drive performance. Harvard Business Review, 70 (1), 71-79 (1992).

4. R. S. Kaplan, Conceptual foundations of the balanced scorecard. Handbook of Management Accounting Research, 3, 1253-1269 (2008).

5. R. S. Kaplan, D. P. Norton, Putting the balanced scorecard to work. Harvard Business Review, 71 (5), 134-142 (1993).

6. R. S. Kaplan, D. P. Norton, The balanced scorecard: translating strategy into action (Harvard Business School Press, Boston, 1996).

7. R. S. Kaplan, D. P. Norton, B. Rugelsjoen, Managing alliances with the balanced scorecard. Harvard Business Review, 88 (1-2 SI), 114-120 (2010).

8. U. Doraszelski, J. Jaumandreu, R and D and productivity: Estimating endogenous productivity. Review of Economic Studies, 80 (4), rdto 11, 1338-1383 (2013).

9. T. B. Lawrence, Institutional strategy. Journal of Management, 25 (2), 161-187 (1999).

10. L. S. Maisel, Performance management: The balanced scorecard approach. Journal of Cost Management, 6 (2), 47-52 (1992).

11. N. Malholtra, C. Hinings, An organizational model for understanding internationalization processes. Journal of International Business Studies, 41 (2), 330349 (2010).

12. P. R. Niven, Create a balanced scorecard of robust measures, meaningful targets, and strategic initiatives (John Wiley \& Sons Inc., Hoboken, NJ, 2014, A).

13. P. R. Niven, Integrating change management techniques to drive balanced scorecard success (John Wiley \& Sons Inc., Hoboken, NJ, 2014, B).

14. P. R. Niven, Let everyone demonstrate their contribution by cascading the balanced scorecard (John Wiley \& Sons Inc., Hoboken, NJ, 2014, C).

15. J. N. Pearson, H. D. Feldman, J. S. Bracker, The impact of the product production process interaction of the evolution of the strategic response. Journal of Management Studies, 28 (2), 161-172 (1991). 
16. J. Van Biesebroeck, Productivity dynamics with technology choice: An applicftion to automobile assembly. Review of Economic Studies, 70 (1), 167-198 (2003).

17. S. Krylov, N. Ilysheva, Integrated management analysis of innovation performance in conditions of globalization. Proceedings of the $16^{\text {th }}$ international scientific conference on globalization and its socio-economic consequences (Rajecke Teplice, Slovak Republic, 734-740, 2016).

18. S. Krylov, N. Ilysheva, Strategic financial analysis based on balanced scorecard in present-day economic environment. Proceedings of the $17^{\text {th }}$ international scientific conference on globalization and its socio-economic consequences (Rajecke Teplice, Slovak Republic, 1194-1201, 2017).

19. S. Krylov, Strategic customer analysis based on balanced scorecard in present-day economic environment. Proceedings of the $18^{\text {th }}$ international scientific conference on globalization and its socio-economic consequences (Rajecke Teplice, Slovak Republic, 656-663, 2018). 